\title{
THE LEATHERY TURTLE OR LUTH
}

\section{INTRODUCTION}

The Leathery Turtle, Dermochelys coriacea, the largest living Chelonian, is a creature of great antiquity-a survival from the time of the dinosaurs. It is the only representative of the suborder Athecae and is distinguished from other turtles by the absence of a true shell covered by large plates; it has instead a mosaic of small bony platelets embedded in its skin.

The species is generally distributed in tropical seas and sometimes strays into cooler waters; examples have been found up in the North Sea off Western Norway $\left(60^{\circ} 31^{\prime}\right.$ N.) and as far south as Chile. A recent inquiry made by the I.U.C.N. Survival Service Commission into the status of the Leathery Turtle revealed that although isolated turtles continue to appear in widely separated parts of the world-La Parguera, Puerto Rico, one in $1958^{1}$; Jamaica, two in $1959^{2}$; Nosy-Bé, Madagascar, one in $1960^{3}$; Whitehaven, England, one in 1960-their breeding places are extremely restricted, and reports point to a steady reduction in numbers.

When Leathery Turtles are reported it is usually because they have become entangled in fishing nets, and their survival in captivity is short. The 5 cwt. "Whitehaven Turtle" was more fortunate; hauled aboard a motor fishing vessel from a depth of 22 fathoms, it was taken to Whitehaven by the skipper who thought it might be given to some zoo, but on the advice of an R.S.P.C.A. officer it was returned to the sea.

The Leathery Turtle is an infrequent visitor to Australian coasts, but all states, including Tasmania, have records of its appearance, some of which are recent. Rare and occasional migrants reach the shores of South Africa. Formerly it was common off the west coast of India and around Ceylon and came ashore to nest in both countries. Now it seems probable that there are only two nesting assemblages of the Leathery Turtle left, one in Costa Rica, the other in Malaya.

Professor Archie Carr, of Florida University-whose book, The Windward Road, led to the formation of the Brotherhood of the Green Turtle and started an active conservation programme designed to remedy past over-exploitation-made a

A male, weighing 3 cwt. $83 \mathrm{lb}$. 
study of the "trunkback" 1 turtles at Matina rookery, Costa Rica. This is a small nesting colony on a 4-mile stretch of beach. A few stragglers nest at the green turtle beach at Tortuguero nearby. Egg hunters from all the nearby inland towns compete for the eggs which sell at 75 centimos a dozen; none are willingly left.

Collecting of the eggs is a serious threat to the continuation of the species. Now and then an adult Leathery Turtle ends up in the slaughter house (particularly in Jamaica), but as a rule its flesh is not considered palatable. In India it is even thought to be poisonous at times. The fact that these turtles tend to congregate for nesting in a very limited area makes them especially vulnerable.

Members of the Malayan Nature Society, and in particular Professor Hendrickson of the University of Malaya in Kuala Lumpur, are fully aware of the threat to the turtle and have taken steps to bring to the notice of their government the urgency of introducing a conservation clause in the licences to eggcollectors at Trengganu, the only sizable rookery of the Leathery Turtle in the world. As a result of their efforts, \$2,000 Malayan have been voted for the purchase of eggs and running of a hatchery from June to September in 1961, and members of the Society have volunteered to help with work at the beach. The following extracts from the Malayan Nature Journal give details of the scheme.

\section{The Leathery Turtle in Malaya}

The Luth does not seem to be commonly known by that name in Malaya. It is more generally known by its alternative name of Leathery Turtle, but even this is usually corrupted in newspaper reporting to "Leather-necked Turtle" or "Leather-backed Turtle".

Until 1952 this species was thought by scientists to be extinct, but then it was reported to be visiting the coast of Trengganu in large numbers for breeding. This does not mean that this habit only started in 1952 -it was just that zoologists did not know about it, and the Malay who has the present contract for gathering eggs, assures me that he first did so, in the steps of his father, forty years ago. Moreover, there are folklore stories in the coastal kampongs of the area, involving the Luth. These stories include references to events in Malay history supposed to

1 Popular name for the Leathery Turtle in the Western Hemisphere. Garman (1884) makes a distinction between an Atlantic and a Pacific sub-species, but no real grounds for this separation have been shown. 
be a hundred years ago. Older stories also refer to turtles, but on the whole the impression is that they refer to smaller creatures.

The Luth grows to a length of 8 feet, and has been recorded to weigh half a ton. However, most of those to be seen today are about 5 to 6 feet in length, and are about 500 to $600 \mathrm{lb}$. in weight. This is still a lot of turtle and the size is very impressive when one gets close. The strength of the creature matches its weight, and it does not seem to be in the least inconvenienced if two men ride on its back up the sandy beach. This is quite easy to do, for once the female comes from the sea to lay her eggs, she is utterly intent on the task, and will not be interrupted by anyone. Onlookers are ignored : the Luth never sees a man at any other time, and probably has no idea of his capacity to inflict harm. As the female drops her eggs, a man may collect them, while others photograph the scene with a flashlight camera (for it is always at night), without the slightest reaction. Instinct outweighs intelligence.

Except to lay eggs, the Luth does not come ashore at all, and of course only the females come ashore for this purpose. This seems to have a number of evolutionary implications. Firstly, the female must retain the ability to cross a couple of hundred yards of sand. The male has no such need. This gives rise to the possibility of differential evolution-or so it seems to an amateur. If the female needs for ever to retain the power of dry-land locomotion, she must develop physically differently from the male who does not. This may contain the cause for extinction of the species.

Secondly, when the female comes ashore, she is almost completely defenceless. She cannot flee enemies, and lacks an effective weapon of self-defence. There are written records of tigers taking the eggs of the Luth, and also that the tiger finds no difficulty with the tough, leathery shield that she wears. If the tiger does find the flesh an attractive food, the only thing that saves the Luth from massacre is the presence of coastal kampongs in the egg-laying area. Even this protection is probably offset by the egg gathering that goes on. At best the future of the species is not too bright.

Its great size is sufficient identification of the Luth for the next largest Chelonian is a terrestrial species found in the Galapagos Islands, whose maximum size is about $500 \mathrm{lb}$. There are other points of differentiation also, notable amongst them being the shell from which the creature takes the better known of its common names. It is in fact no shell at all, but a heavy, 
flexible, leathery shield on the turtle's back, an abnormal type of carapace with no corresponding plastron. In colour the shield seems to be dark blue (it is rarely seen except at night, by artificial light), and is inset with apparent flakes of pale blue shell or some horny material. It is as though the flakes which have joined to form the carapace in other turtles have failed to develop and join in the Luth. Another distinguishing feature is a series of rough, horny ridges that run along the creature's back. The books all say that there are seven of these, but I have seen only five. The books, I think, count the lines on either side where the shield becomes continuous with the under-belly skin.

It is not clear why the Luth should have a leathery shield as it does, instead of the normal shell. It may have something to do with the great depths to which it is said to descend. It is believed to go half a mile below the surface of the sea and at this depth it would be subject to great pressure. If this is so, then the theory of physics, that liquids exert pressure equally in all directions, probably comes into play: at depth, the Luth may become nearly spherical in shape. The water pressure would lead to this, and the flexibility of the shield would facilitate it. I have not been able to confirm this from any book, but an engineer with whom I discussed it agreed with the idea as a possibility.

When the Luth comes from the depths to lay her eggs, she usually surfaces several miles out at sea, and congregates in herds which are easily seen from the air at the right season. The herds disperse before they come ashore, and the females cross the beach rather as individuals, though often very close to their fellows. They mount the beach to a point just beyond the high tide line, leaving a track like the path of a military tank.

All the while they puff and pant, and seem almost to choke for breath as they begin the laborious task of digging the hole in which the eggs are to be laid. This no doubt is because their mouths, usually full of water, are dry.

The egg hole is sunk in damp sand, and the work is done by cupping a small quantity of sand in each rear flipper alternatively and casting it away to the rear. By the time the hole has been sunk to the required depth, the struggling and writhing that has accompanied this unusual labour has imbedded the female Luth in the sand to a depth of about $18 \mathrm{in}$. and she protrudes about the same degree above the level of the surroundings. Below this the hole is about $2 \mathrm{ft}$. deep.

The eggs are dropped into the hole (not lowered gently, as a 
recent book about Malaya claims) singly or in groups of two or three. They are spherical, about the size of a billiard ball, and have a flexible shell as with the eggs of any other turtle. They are wet and glistening when dropped. About 100 up to 120 constitute the usual clutch, and any in excess of this number taper off in size to the size of marbles. They also lack a yolk, and of course are infertile.

When the eggs are laid the female goes to great trouble to hide the location of the hole. It is impossible to hide the immediate area because of the highly distinctive tracks leading to and from it, but by the time she has finished scattering sand in great sweeps of her fore and hind flippers, there is an area about 15 yards in diameter at the end of these tracks. The eggs are in an area of about $1 \frac{1}{2}$ square feet, somewhere within this outer circle. The whole process of digging, laying, and camouflage takes about two hours. The weary creature then struggles back to the cooling sanctuary of the South China Sea.

The eggs are left to hatch in the sand, and the intended result is that the young turtles when they emerge from the shell will struggle upwards through the sand to the surface, and then waddle down to the water. Heavy casualties occur at two stages.

Each morning during the laying season a licensed contractor patrols the beach to collect as many eggs as he can find by probing with a thin iron rod in the areas where eggs have been laid. The contractor pays the Government a sum annually for the right to gather eggs over the few miles of coastline north of Dungun, and I was told that the contract price was $\$ 18,000$ in 1958. I could gather no information about what proportion of eggs are actually collected ; there seemed to be a suggestion that more are gathered than ought to be under the terms of the contract. They sell at 10 cents each in local shops, and are said to be of high food value. When cooked the white does not normally harden as it does in a hen's egg, but the taste is almost indistinguishable.

The second hazard is after the hatching, during the pilgrimage to the water. As soon as the young turtles break surface they are the prey of hundreds of sea birds, and as soon as they near the water, they are attacked by hordes of small crabs. Few survive.

These two large-scale massacres would seem to tend to the elimination of the species, but the kampong people in the locality say that there are more Luths visiting the beach now than there were some years ago. I believe that someone has attempted a count, but have not been able to discover either who this was 


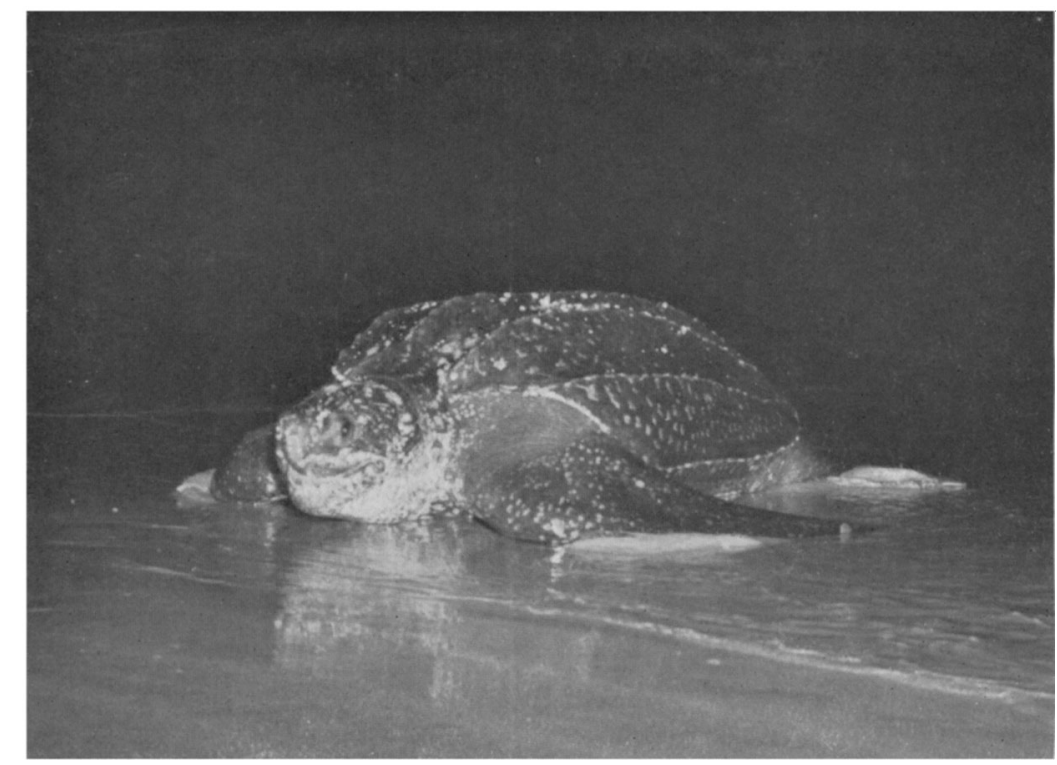

Photo: Department of Information, Malaya. FEMALE LEATHERY TURTLE LEAVING THE SEA TO LAY, MALAYA.

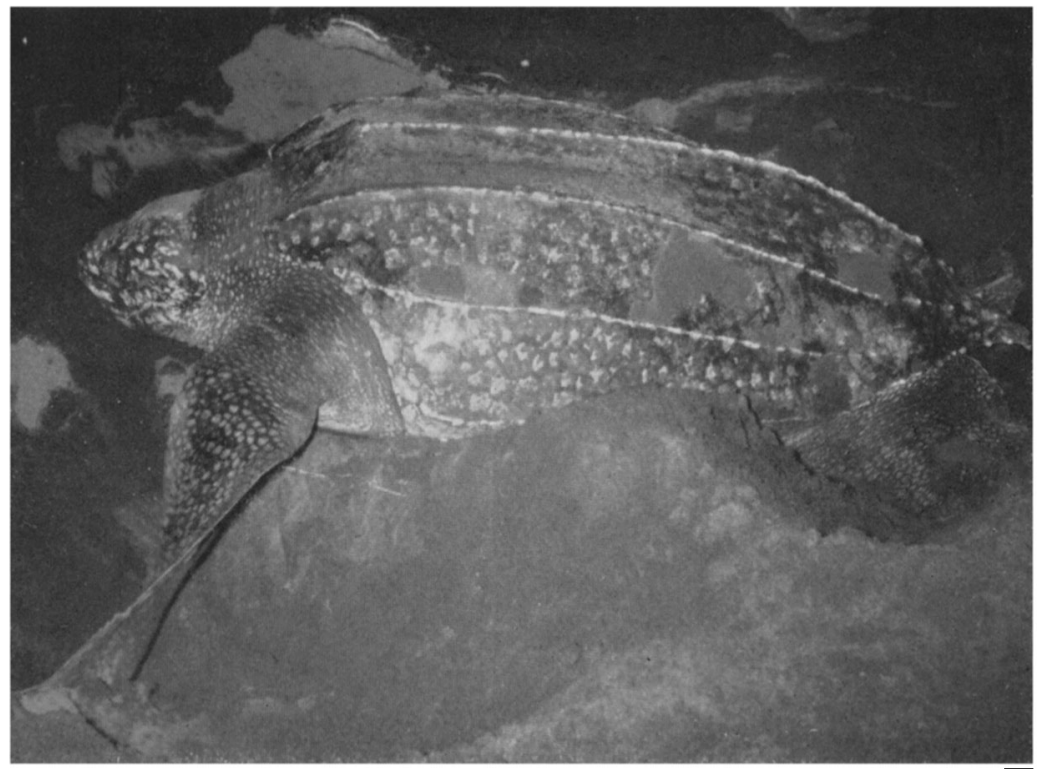

Photo: Archie Carr.

THE LEATHERY TURTLE DIGGING, COSTA RICA. 


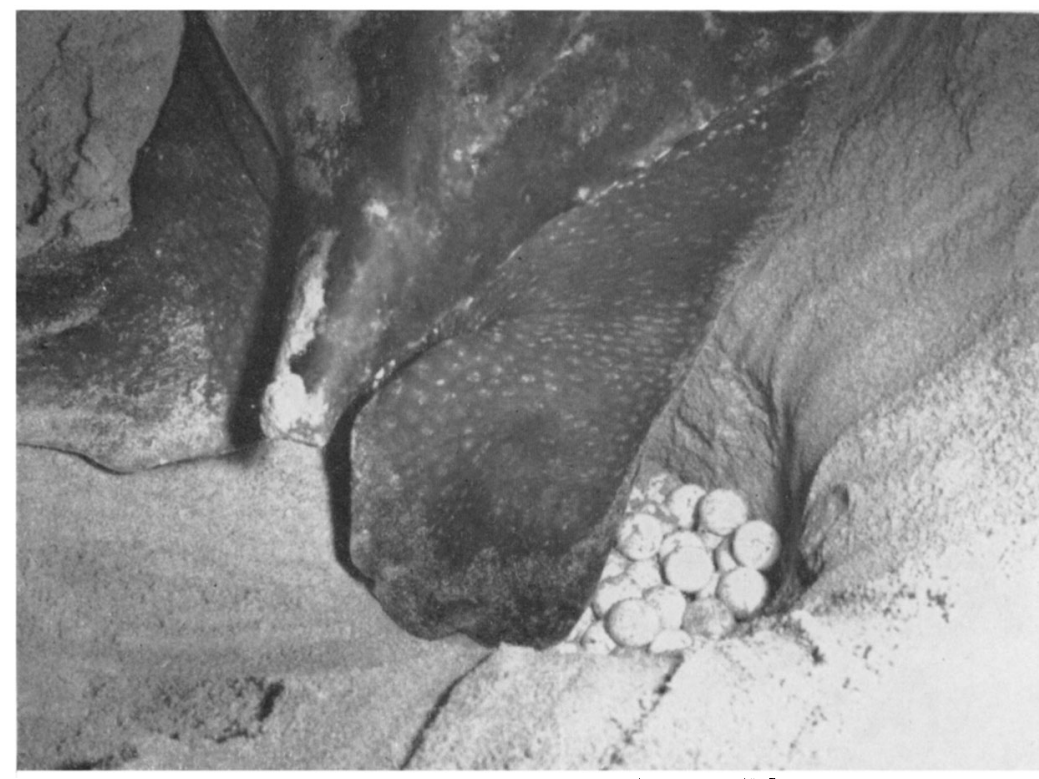

Photo: Department of Information, Malaya. THE LEATHERY TURTLE LAYING EGGS, MALAYA.

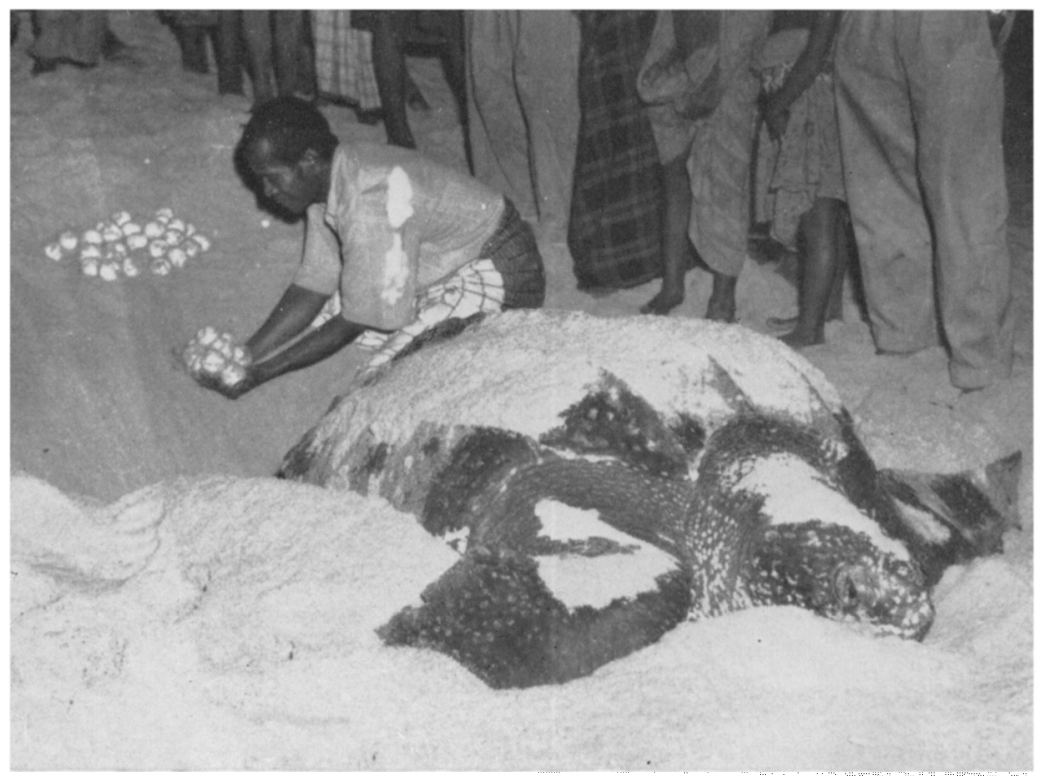

Photo: Department of Information, Malaya. THE HEADMAN OF KAMPONG COLLECTING THE RGGS, MALAYA. 


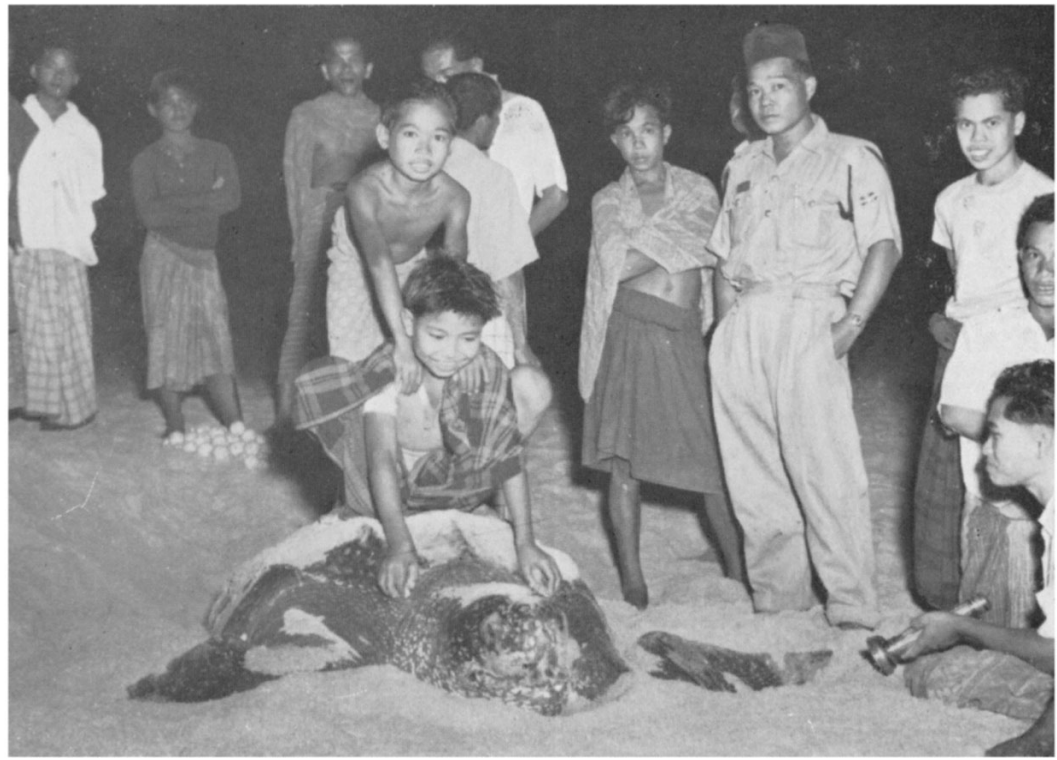

Photo: Department of Information, Malava.

LEATHERY TURTLE RETURNING TO THE SEA.

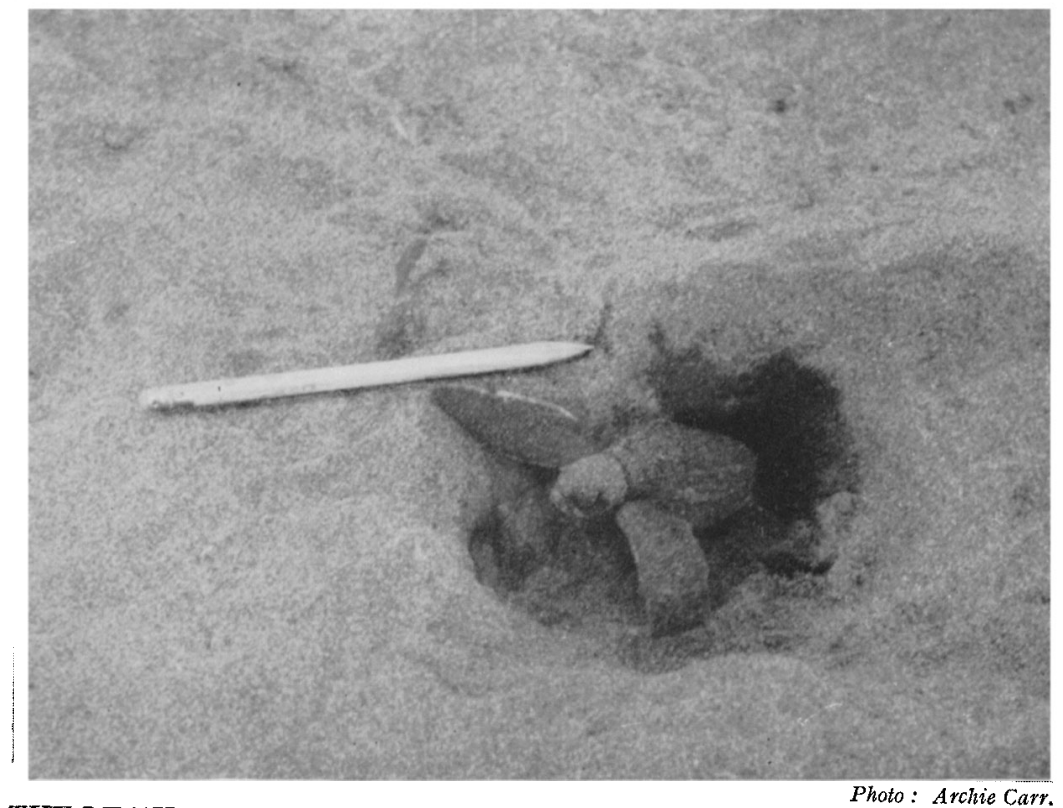

THE LEATHERY TURTLE EMERGING FROM THE SAND, COSTA RICA. 
or the results. Over eighty visited the beach one night just before I was there in August, and the pilot of an aircraft at the same time saw six flocks at sea, about forty strong.

While she lays her eggs, the lady Luth weeps long tears which don't fall, but which hang in strings of mucous from her piggy eyes. These strings soon become covered with sand, and frequently this is true of the eyes too. One of the more romantic books claims that this is in some way the result of the pain of laying so many eggs, but I feel that it is rather the result of there being no water to carry the normal duct flow away from the Luth's eyes. So also with the heavy grunting and hissing and swallowing that accompanies the whole progress : the Luth is dry with the dryness of a thirsty man in a desert.

In eating habits the Luth is said to be carnivorous, living on small fish, molluscs, and other minor forms of marine life. I have found no reference to edibility of the Luth's flesh, but people in the kampongs along the Trengganu coast insist that it is not palatable. They admit, on the other hand, that they do no remember any occasion when anyone tried to eat it. The theory of inedibility may originate in a folklore method of protecting the supply of nutritious eggs, buttressed more recently by controlling legislation.

All told, the Luth is one of the most interesting creatures in Malaya's fauna, and one which, being peculiar to this country, is worth some effort to preserve.

\section{Conservation}

A Memorandum on the Conservation of the Leathery Turtle was submitted to the Trengganu Government on 15th March, 1960, by the President of the Malayan Nature Society, Mr. J. Wyatt-Smith. It describes the status of the turtle and suggests a practical and inexpensive scheme for conservation as follows :

\section{Numbers in Malaya}

From estimates of egg production and known habits of other related turtle species, the following calculations can be made as to the size of the population in Trengganu : an estimated 850,000 eggs are laid per year (June-August) divided by 100 eggs per nest on the average gives 8,500 nests per year. Divided by five nests per female at the predictable minimum and ten nests per female at the predictable maximum, one concludes that there are at least 850 females and at most 1,700 females laying each year.

Present knowledge is insufficient to allow prediction of the 
sex ratio, which is probably low for males in relation to females. Likewise, it is not known for certain whether each female turtle lays eggs every year or not. For the moment it is necessary to assume that the sex ratio is adequate for fertilization of the available females, that it will stay in adequate adjustment with changes in the female population, and that each female probably does nest almost every year.

The critical area of beach in Trengganu is very distinctive and the turtles seem to choose only this type for nesting ; apparently no substitute locations elsewhere in Malaya will do, since nests are found only very rarely on any beaches outside the critical $7 \frac{1}{2}$ mile stretch in Trengganu. Other species of sea turtles have their own preferences also, but the types of nesting beaches preferred by these other species are very extensive and the turtle species themselves seem better able to adapt to a variety of beach types than are Leathery Turtles.

\section{Numbers in the World}

There is little reason to doubt that the Trengganu turtles represent a very large majority of the individuals of this species still living in the world today. Based on the available figures, it is believed that there may be as few as 1,000 pairs of the species left alive today, between 85 per cent and 95 per cent of these using the $7 \frac{1}{2}$ miles of Trengganu beach for breeding.

\section{Egg Collection Licenses in Trengganu, Malaya}

All $7 \frac{1}{2}$ miles of the Leathery Turtle nesting beach are licensed by Government for the collection of turtle eggs. The tender prices for the two important licensed areas of Rantau Dalam and Rhu Kubor for 1959 were $\$ 11,565.00$ and $\$ 7,855.00$ respectively, and the average cost of 100 eggs in the Kuala Trengganu market that year was $\$ 8.00$.

\section{Natural Losses}

Sea turtles, like many fish, seem to suffer enormous natural losses in the earlier stages of their life history. Crabs, birds, monkeys, monitor lizards and other predators prey on the incubating nests and on the young turtles making their way to the water. Probably at least 50 per cent of the young reaching the sea are eaten by fish during their first hour or so in the water. Of those surviving this shallow water attack, probably threequarters are eaten by deep water fish during the first week. For every 1,000 babies hatched (and many eggs are eaten or damaged in the nest), only about 500 survive the first hour 
in the water and only about 125 live to be a week old. These heavy losses with each continuing week occur through the first year at least, leaving only one or two survivors from the large original numbers of eggs. In an undisturbed natural state, however, this is enough-if only one male and one female turtle grow to maturity from each adult female's large total of eggs laid in her lifetime, they will replace the parents which die of old age and keep the species' number constant. However, it will be seen that this large original production of eggs is necessary to keep the species from declining. If it is reduced drastically by human collection of the eggs, then too few young will grow to maturity and the population will decline as the older individuals die off without being replaced.

\section{Effect of Harvesting Eggs}

Now it so happens that a very small fraction of the losses which are suffered in nature occur during the time of incubation in the underground nests. When all the nests are harvested for human consumption, this large fraction is not added damage to the species-it is only diverted damage (from natural causes to human causes). If the remaining fraction of eggs were given simple protection against natural threats by transplanting some nests to a fenced area or hatchery, the fraction of loss concerned here could be considered an earned crop, taken without threat to the survival of the species (and the turtle egg industry).

Further, if those young turtles which hatched from the transplanted nests in the fenced hatchery were prevented from moving straight to the water, but were collected and scattered widely about 100 yards out from shore, another very large fraction of the natural losses would have been avoided by simple care; and another large fraction of the eggs harvested for eating could be considered as an earned crop without threat to the species and the egg industry.

\section{Egg Collection Licenses and Absence of Conservation Clause}

The licensee, who has been granted the licence of a particular portion of the beach for any one year, has a monopoly because he submitted the highest bid when tenders were called for. Therefore, it is logical that he will try to harvest 100 per cent of the nests laid in his licensed area. He is not, unfortunately, bound by existing terms of the tender notice to leave any of the eggs in each nest, but in practice the licensee at Rantau Dalam is leaving four or five eggs per nest, or at least was doing so in 1959. There is provision, however, under section 9 (1) of 
the present Turtles Enactment, No. 4, 1951, Trengganu, to impose a conservation clause in tender notices and licenses.

In fact, however, when as few as four or so eggs out of a nest of 100 are left buried deep in the ground, they constitute a total loss. It has been clearly demonstrated that there is almost no chance of so few baby turtles being able to dig their way through 2 or $3 \mathrm{ft}$. of sand to the surface - it takes at least forty or fifty baby turtles together to emerge to the surface successfully. The result of the present licensing arrangement is therefore that virtually 100 per cent of all Leathery Turtle nests in Malaya, or in other words almost the entire stock for the world, is being destroyed.

\section{Suggested Conservation Method}

If complete nests were left undisturbed, development would be normal and escape to the surface would be possible. As any turtle egg collector knows, however, many such nests would be destroyed by other turtles clumsily digging new nests, many would be reached and despoiled by burrowing crabs, many would be harvested by poachers, etc.

For really effective conservation it is suggested $(a)$ that eggs should be transplanted into a simple enclosure in a convenient place on the beach where heavy posts will discourage nesting turtles and predators and where poachers could be kept away, and $(b)$ that the young turtles on hatching should be kept for about one week and then released from a boat over a wide area and at some distance from the shore in order to reduce the effect of predators.

This transplanting to a hatchery need not be a daily operation. It makes no difference to conservation whether a certain percentage of every nest of each day is transplanted or whether the eggs of all the nests on about two selected days during the height of the season are transplanted. The latter is the more practical and cheaper solution and is, in fact, depriving the licensees of no more eggs than the licensee at Rantau Dalam was setting aside, albeit to no purpose, in 1959. It is hoped that such a condition will be inserted in future tender notices and licenses.

The cost of this suggested method would not be great. It would merely involve $(a)$ the formation of a hatchery (posts, a few tanks and some fencing) which could be designated a " notified area" under section 8 of the Turtles Enactment, 1951, (b) sufficient labour to collect and rebury the eggs for those few days and to protect the hatchery from poachers for about two to three months, protection in which the licensee 
would probably be glad to assist, and (c) the hire of a boat to release the young turtles. The expenditure would thus only be incurred for a little over two months each year, and would be a small sum compared with the present annual revenue-an average of over $\$ 22,000$ per year during the past five years for the two beaches of Rantau Dalam and Rhu Kubor, alone.

\section{THE START OF THE HATCHERY}

Mr. Oliver Milton writes from Kuala Lumpur on 26th June, 1961 : "Last week end a large group of Malayan Nature Society members went to the east coast to collect eggs of the Leathery turtle. About fifty people went from here, some by hired bus which was pretty tiring, and a dozen or so came up from Singapore. On the first night small groups of us were stretched out along the 15 mile beach at Dungun, north and south of the prepared enclosure which was to be used for the hatchery. I was on the south part and for some reason saw no turtles that night at all-they were all going to the north section. About 5,000 eggs were collected, On the next night everyone concentrated on the northern bit. Most of the turtles came to the very north portion and so the people there had a very long walk to bring the eggs back.

I worked in the hatchery planting the eggs as they were brought in. One dug a hole in the damp sand about the width of the arm up to the armpit and then excavated a small chamber the size of a soccer ball in the bottom. The eggs were then placed in this chamber, the hole refilled with damp sand and marked with a small metal plate on a stick. The nest number and the quantity of eggs were recorded in a book. Some nests contained thirty or so eggs while the most was 161 . The average was about ninety. During the two nights we buried about 8,500 eggs, which was, I think a little less than we expected. The licensed egg collector was paid 3 United States dollars per hundred for the eggs."

\section{REFERENCES}

Carr, A., and OGren, L. The Ecology and Migrations of Sea Turtles 3, Dermochelys in Costa Rica. American Museum Novitates, number 1958, 5th August, 1959.

WeLrs, K. L. A note on turtles. Malayan Nature Journal, Vol. 14, No. 2, January, 1960, pp. 108-121.

Wyatr-Smith, J. The conservation of the Leathery Turtle. Malayan Nature Journal, Vol. 14, Nos. 3-4, July, 1960, pp. 194-9. 